\title{
"WHAT IF" ANALYSES IN INVESTMENT DECISION MAKING
}

\author{
Katarína Belanová \\ University of Economics in Bratislava \\ Dolnozemská Street 1, 85235 Bratislava, Slovakia \\ katarina.belanova@euba.sk
}

\begin{abstract}
In general, each project's value is estimated using a discounted cash flow (DCF) valuation, and the opportunity with the highest value, as measured by the resultant net present value (NPV) will be selected. The problem with such NPV estimates is that they depend on projected future cash flows. If there are errors in those projections, then estimated net present values can be misleading (a forecasting risk). Basic approach to evaluating cash flow and NPV estimates involves asking "what - if" questions. Accordingly, the paper discusses some organized ways of going about a what - if analysis. Its goal in doing so is to assess the degree of forecasting risk and to identify those elements that are the most critical to the success or failure of an investment. However, as we show in examples, as well as in the practical study, though what - if analysis really allows us to obtain the certain idea of degree of forecasting risk, it does not tell us what to do about the possible errors.
\end{abstract}

Keywords: forecasting risk, net present value, discounted cash flow valuation, scenario analysis, sensitivity analysis, simulation analysis

\section{JEL Classification: G31}

\section{Introduction}

While "what - if" analysis can be considered as a relatively recent discipline, its background is rooted at the confluence of different research areas, some of which date back to same decades ago. Simulations are used in a wide variety of practical contexts, including physics, chemistry, biology, engineering and chemistry. Concerning economy, it provides the insights into business processes necessary to build and test simulation models.

There are a number of papers related to "what - if" analysis in the literature. We come out mostly from the newest foreign monographs by the elaboration of the paper (Danielsson, 2011; Saltelli, 2000; Škrovánková, 2007; Campolongo, 2000; Chan, 1999). Concerning the scientific methods, we used the standard methods of investigation such as the analysis and deduction. Analysis helped us to break a DCF analysis into smaller parts to get a better understanding of it, whereas deduction allowed us to clarify the more universal, general notion to a less general one. 
Our primary concern of this article is, that after the coming up with a preliminary estimate of the NPV for a proposed project, it is useful to focus on assessing the reliability of such an estimate. We begin by discussing the need for an evaluation of cash flow and NPV estimates. We go on to develop some tools that are useful for doing so. Finally, at the end we show the use of "what - if" analysis in practice.

\section{Discounted cash flow analysis and forecasting risk}

Evaluation of a proposed investment ${ }^{1}$ can be divided into three steps:

1. decision which cash flows are relevant and which are not (calculation of their present values);

2. calculation of net present value (NPV) (or other investment criteria);

3. including the forecasting risks (Belanová, 2009; Belanová, 2010).

Suppose we are working on a preliminary discounted cash flow analysis. We carefully identify the relevant cash flows, avoiding such things as sunk costs, and we remember to consider working capital requirements. We add back any depreciation, we account for possible erosion; and we pay attention to opportunity costs. Finally, we double - check our calculations, and, when all is said and done, the bottom line is that the estimated NPV is positive (Škrovánková, 2007).

Now what? Do we stop here? Probably do not. The fact that the estimated NPV is positive is definitely a good sign, but, more than anything, this tells us that we need to take a closer look, or, in another words, we have to assess the reliability of such an estimate.

There are two circumstances under which a DCF analysis could lead us to conclude that a project has a positive NPV. The first possibility is that the project really does have a positive NPV. That is the good news. The bad news is the second possibility: a project may appear to have a positive NPV because our estimate is inaccurate.

Of course, we could err in the opposite way. If we conclude that a project has a negative NPV when the true NPV is positive, then we lose a valuable opportunity. ${ }^{2}$

The possibility that we make a bad decision because of errors in the projected cash flows is called forecasting risk (or estimation risk). Because of forecasting risk, there is

\footnotetext{
${ }^{1}$ We mean capital investment, i.e. money invested in a business venture with an expectation of income, and recovered through earnings generated by the business over several years.

${ }^{2}$ If the projected future cash flows are seriously in error, then we have a classic GIGO (garbage - in, garbage - out) system. In this case, no matter how carefully we arrange the numbers and manipulate them, the resulting answer can still be grossly misleading. This is the danger in using a relatively sophisticated technique like DCF. It is sometimes easy to get caught up in number crunching and forget the underlying nuts - and bolts economic reality.
} 
the danger that we think a project has a positive NPV when it really does not. It happens mostly if we are overly optimistic about the future and, as a result, our projected cash flows do not realistically reflect the possible future cash flows (Danielsson, 2011; Connor, 2010).

Fortunately, we can find some tools that are useful in identifying areas where potential errors exist and where they might be especially damaging. In one form or another, we will be trying to assess the economic "reasonableness" of our estimates. We will also be wondering how much damage will be done by errors in those estimates.

The first line of defence against forecasting risk is simply to ask: What is it about this investment that leads to a positive NPV? For example, if the proposal under consideration involved a new product, then we might ask questions such as: "Are we certain that our new product is significantly better than that of the competition? Can we truly manufacture at lower cost, or distribute more effectively, or identify undeveloped market niches, or gain control of a market?"

These are just a few of the potential sources of value. There are many others. A key factor to keep in mind is the degree of competition in the market. It is a basic principle of economics that positive NPV investments will be rare in a highly competitive environment. Therefore, proposals that appear to show significant value in the face of stiff competition are particularly troublesome, and the likely reaction of the competition to any innovations must be closely examined.

The point to remember is that positive NPV investments are probably not all that common, and the number of positive NPV projects is almost certainly limited for any given firm. If we cannot articulate some sound economic basis for thinking ahead of time we have found something special, than the conclusion that our project has a positive NPV should be viewed with some suspicion.

\section{Scenario and other "What If" analyses}

When we are investigating a new project, the first thing we do is estimate NPV based on our projected cash flows (the base case). Afterwards we recognize the possibility of errors in those cash flow projections and so we wish to investigate the impact of different assumptions about the future on our estimates.

One way to organize this investigation is to put an upper and lower bound on the various components of the project. For example, suppose we forecast sales at 100 units per year. We know this estimate may be high or low, but we are relatively certain that it is not off by more than 10 units in either direction. We would thus pick a lower bound of 90 and an upper bound of 110 . We go on to assign such bounds to any other cash flow components that we are unsure about. 
When we pick these upper and lower bounds, we are not ruling out the possibility that the actual values could be outside this range. What we are saying, again loosely speaking, is that it is unlikely that the true average (as opposed to our estimated average) of the possible values is outside this range.

An example is useful to illustrate the idea here. The project under consideration costs $\$ 200,000$, has a five - year life, and no salvage value. Depreciation is straight - line to zero. The required return is $12 \%$, and the tax rate is $34 \%$. In addition, we have compiled the following information (see Tab. 1).

Tab. 1 Values for NPV calculation

\begin{tabular}{|l|c|c|c|}
\hline & Base case & Lower bound & Upper bound \\
\hline Unit sales & 6,000 & 5,500 & 6,500 \\
\hline Price per unit & $\$ 80$ & $\$ 75$ & $\$ 85$ \\
\hline Variable costs per unit & $\$ 60$ & $\$ 58$ & $\$ 62$ \\
\hline Fixed costs per year & $\$ 50,000$ & $\$ 45,000$ & $\$ 55,000$ \\
\hline
\end{tabular}

Source: Author`s calculation

With this information, we can calculate the base - case NPV by first calculating net income:

$\begin{array}{lr}\text { Sales } & \$ 480,000 \\ \text { Variable costs } & 360,000 \\ \text { Fixed costs } & 50,000 \\ \text { Depreciation } & 40,000 \\ \text { EBIT } & \$ 30,000 \\ \text { Taxes }(34 \%) & 10,200 \\ \text { Net income } & \$ 19,800\end{array}$

Operating cash flow is thus $\$ 30,000+40,000-10,200=\$ 59,800$ per year. At $12 \%$, the five - year annuity factor is 3.6048 , so the base - case NPV is:

Base - case NPV $=-\$ 200,000+\$ 59,800 \times 3.6048=\$ 15,567$

Thus, the project looks good so far.

\section{Scenario analysis}

The basic form of what - is analysis is called scenario analysis. What we do is investigate the changes in our NPV estimates that result from asking questions like "What if unit sales realistically should be projected at 5,500 units instead of 6,000 ?" 
Once we start looking at alternative scenarios, we might find that most of the plausible ones result in positive NPVs. In this case, we have some confidence in proceeding with the project. If a substantial percentage of the scenarios look bad, then the degree of forecasting risk is high and further investigation is in order (Chun, 1992).

There are a number of possible scenarios we could consider. A good place to start is the worst - case scenario. This will tell us the minimum NPV of the project. If this were positive, we would be in good shape. While we are at it, we will go ahead and determine the other extreme, the best case. This puts an upper bound on our NPV (Saltelli, 2004).

To get the worst case, we assign the least favourable value to each item. This means low values for items like units sold and price per unit and high values for costs. We do the reverse for the best case. For our project, these values would be (see Tab. 2):

Tab. 2 Values for cash flow calculation

\begin{tabular}{|l|c|c|}
\hline & Worst case & Best case \\
\hline Unit sales & 5,500 & 6,500 \\
\hline Price per unit & $\$ 75$ & $\$ 85$ \\
\hline Variable costs per unit & $\$ 62$ & $\$ 58$ \\
\hline Fixed costs & $\$ 55,000$ & $\$ 45,000$ \\
\hline
\end{tabular}

Source: Author`s calculation

With this information, we can calculate the net income and cash flows under each scenario (see Tab. 3):

Tab. 3 Results under the considered scenarios

\begin{tabular}{|c|c|c|c|c|}
\hline Scenario & Net income $(\$)$ & Cash flow $(\$)$ & NPV $(\$)$ & IRR $(\%)$ \\
\hline Base case & 19,800 & 59,800 & 15,567 & 15.1 \\
\hline Worst case & $-15,510$ & 24,490 & $-111,719$ & -14.4 \\
\hline Best case & 59,730 & 99,730 & 159,504 & 40.9 \\
\hline
\end{tabular}

Note: IRR = Internal rate of return; we assume a tax credit is created in our worst case scenario. Source: Author's calculation

What we learn is that under the worst scenario, the cash flow is still positive at $\$ 24,490$. That's good news. The bad news is that the return is $-14.4 \%$ in this case, and the NPV is - $\$ 111,719$. Since the project costs $\$ 200,000$, we stand to lose a little more than half of the original investment under the worst possible scenario. The best case offers an attractive $41 \%$ return. 
As we have mentioned, there is an unlimited number of different scenarios we could examine. At a minimum, we might want to investigate two intermediate cases by going halfway between the base amounts and the extreme amounts. This would give us five scenarios in all, including the base case.

Beyond this point, it is hard to know when to stop. As we generate more and more possibilities, we run the risk of "paralysis of analysis." The difficulty is that no matter how many scenarios we run, all we can learn are possibilities, some good and some bad. Beyond that, we do not get any guidance as to what to do. Scenario analysis is thus useful in telling us what can happen and in helping us to gauge the potential for disaster, but it does not tell us whether or not to take the project (Saltelli, 1999).

\section{Sensitivity analysis}

Sensitivity analysis is a variation on scenario analysis that is useful in pinpointing the areas where forecasting risk is especially severe. The basic idea with a sensitivity analysis is to freeze all of the variables except one and then see how sensitive our estimate of NPV is to changes in that one variable. If our NPV estimate turns out to be very sensitive to relatively small changes in the projected value of some component of project cash flow, then the forecasting risk associated with that variable is high (Saltelli, 2007).

To illustrate how sensitivity analysis works, we go back to our base case for every item except unit sales. We can calculate cash flow and NPV using the largest and smallest sales figures (see Tab. 4).

Tab. 4 NPV calculation

\begin{tabular}{|c|c|c|c|c|}
\hline Scenario & Unit sales & Cash flow $(\$)$ & NPV $(\$)$ & $\operatorname{IRR}(\%)$ \\
\hline Base case & 6,000 & 59,800 & 15,567 & 15.1 \\
\hline Worst case & 5,500 & 53,200 & $-8,226$ & 10.3 \\
\hline Best case & 6,500 & 66,400 & 39,357 & 19.7 \\
\hline
\end{tabular}

Source: Author's calculation

By way of comparison, we now freeze everything except fixed costs and repeat the analysis (see Tab. 5).

What we see here is that, given our ranges, the estimated NPV of this project is more sensitive to projected unit sales than it is to projected fixed costs. In fact, under the worst case for fixed costs, the NPV is still positive. 
Tab. 5 NPV calculation

\begin{tabular}{|c|c|c|c|c|}
\hline Scenario & Fixed costs & Cash flow $(\$)$ & NPV $(\$)$ & IRR (\%) \\
\hline Base case & 50,000 & 59,800 & 15,567 & 15.1 \\
\hline Worst case & 55,000 & 56,500 & 3,670 & 12.7 \\
\hline Best case & 45,000 & 63,100 & 27,461 & 17.4 \\
\hline
\end{tabular}

Source: Author`s calculation

The results of our sensitivity analysis for unit sales can be illustrated also graphically (see Graph 1). Here we place NPV on the vertical axis and unit sales on the horizontal axis. When we plot the combinations of unit sales versus NPV, we see that all possible combinations fall on a straight line. The steeper the resulting line is, the greater the sensitivity of the estimated NPV to the projected value of the variable being investigated.

\section{Graph 1 Sensitivity analysis for unit sales}

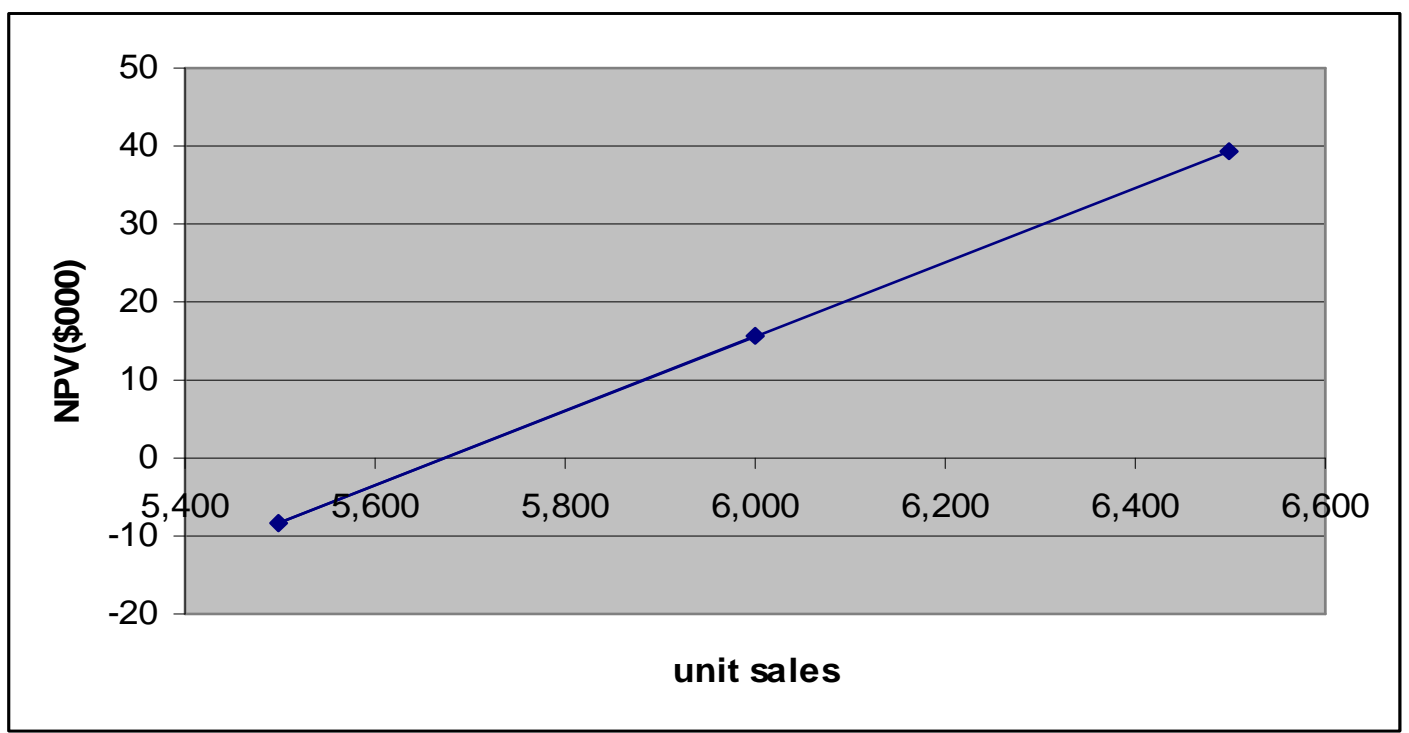

Source: Author`s construction

As we have illustrated, sensitivity analysis is useful in pinpointing those variables that deserve the most attention. If we find that our estimated NPV is especially sensitive to a variable that is difficult to forecast (such as unit sales), the degree of forecasting risk is high. We might decide that further market research would be a good idea in this case.

Because sensitivity analysis is a form of scenario analysis, it suffers from the same drawbacks. Sensitivity analysis is useful for pointing out where forecasting errors will do the most damage, but it does not tell us what to do about the possible errors. 


\section{Simulation analysis}

Scenario analysis and sensitivity analysis are widely used. With scenario analysis, we let all the different variables change, but only let them take on a small number of values. With sensitivity analysis, we only let one variable change, but we let it take on a large number of values. If we combine the two approaches, the result is a crude form of simulation analysis.

If we want to let all the items vary at the same time, we have to consider a very large number of scenarios, and computer assistance is almost certainly needed. In the simplest case, we start with unit sales and assume that any value in our 5,500 to 6,500 range is equally likely. We start randomly picking one value (or by instructing computer to do so). We then randomly pick a price, a variable cost, and so on.

Once we have values for all the relevant components, we calculate NPV. We repeat this sequence as much as we desire, probably several thousand times. The result is a large number of NPV estimates that we summarize by calculating the average value and some measure of how spread out the different possibilities are. For example, it would be of some interest to know what percentage of the possible scenarios result in negative estimated NPVs.

Since simulation is an extended form of scenario analysis, it has the same problems. Once we have the results, there is no simple decision rule that tells us what to do. Also, we have described a relatively simple form of simulation. To really do it right, we would have to consider the interrelationships between the different cash flow components. Furthermore, we assumed that the possible values were equally likely to occur. It is probably more realistic to assume that values near the base case are more likely than extreme values, but coming up with the probabilities is difficult, to say the least.

For these reasons, the use of simulation is somewhat limited in practice. However, recent advances in computer software and hardware (and user sophistication) lead us to believe that it may become more common in the future, particularly for large - scale projects (Law, 2006).

\section{Practical application of "What If" analysis}

Now, after the theoretical explanation of "what - if" analysis, it`s time to demonstrate how we can use it in practice. Let's think of a new product, whose most probable values as well as the values for the situations altogether with the profit are covered in table $6{ }^{3}$ Each of the situations (except situation 1) arose by the combination in changes of two or three inputs determining the project profit. The changes concerned four values, namely size of the sales, price, exchange rate (CZK/EUR) and purchase price of material. The

\footnotetext{
${ }^{3}$ According to Hnilica and Fotr, 2009.
} 
other two input variables (standard of material consumption and fixed costs) did not change and remained in their most probable values under each situation.

First six situations were created as a combination of simultaneous unfavorable change from one to four input variables, namely $\pm 10 \%$ from their most probable values. The good news is that the profit is positive in each case. The highest profit is in situation with the most probable values (90.0 mil. of CZK), whereas the least one in the situation 6 (9.02 mil. of CZK), which arose by a combination of unfavorable changes of three inputs, namely sales, selling price and purchase price of material.

Next situations $(7-11)$ combine favorable, as well as unfavorable changes of the input variables. The least decrease in profit (129.1 million CZK) was under the situation 12, which arose as a combination of the favorable changes of two inputs, namely increase of sales to 110,000 pieces and depreciation to $25.40 \mathrm{CZK} / \mathrm{EUR}$. Situation 9 caused the most significant decrease of profit to 44.4 million CZK.

Tab. 6 Results of "What If" analysis** (part one)

\begin{tabular}{|c|c|c|c|c|c|c|c|}
\hline \multirow{2}{*}{ Variable } & \multirow{2}{*}{ Unit } & \multicolumn{5}{|c|}{ Situation } \\
\cline { 3 - 7 } & & $N^{*}$ & 1 & 2 & 3 & 4 & 5 \\
\hline 1. Sales & $\begin{array}{c}\text { Pcs. } \\
\text { thousands }\end{array}$ & 100 & 90 & 90 & 90 & 90 & 90 \\
\hline $\begin{array}{c}\text { 2. Selling } \\
\text { price }\end{array}$ & EUR/pcs & 150 & 150 & 135 & 150 & 150 & 135 \\
\hline $\begin{array}{c}\text { 3. Exchange } \\
\text { rate }\end{array}$ & CZK/EUR & 24.0 & 24.0 & 24.0 & 22.8 & 24.0 & 24.0 \\
\hline $\begin{array}{c}4 . \text { Standard } \\
\text { of material } \\
\text { consumption }\end{array}$ & Kg/pcs & 50 & 50 & 50 & 50 & 50 & 50 \\
\hline $\begin{array}{c}5 . \text { Purchase } \\
\text { price of } \\
\text { material }\end{array}$ & CZK/kg & 40 & 40 & 40 & 40 & 44 & 44 \\
\hline $\begin{array}{c}\text { 6. Fixed } \\
\text { costs }\end{array}$ & Mil. CZK & 70 & 70 & 70 & 70 & 70 & 70 \\
\hline $\begin{array}{c}\text { Profit } \\
\text { Mil. CZK }\end{array}$ & 90.0 & 74.0 & 41.6 & 57.8 & 11.4 & 23.6 \\
\hline
\end{tabular}

Source: Author's calculation

Note: *Most probable values of the input variables.

** The cells in table 6 containing the variables which changed concerning the most probable scenario are darker. 
Tab. 6 Results of "What If”' analysis (continuation - part two)

\begin{tabular}{|c|c|c|c|c|c|c|c|c|}
\hline \multirow{2}{*}{ Variable } & \multirow{2}{*}{ Unit } & \multicolumn{7}{|c|}{ Situation } \\
\hline & & 6 & 7 & 8 & 9 & 10 & 11 & 12 \\
\hline 1. Sales & $\begin{array}{c}\text { Pcs. } \\
\text { thousands }\end{array}$ & 90 & 110 & 110 & 110 & 110 & 110 & 110 \\
\hline $\begin{array}{l}\text { 2. Selling } \\
\text { price }\end{array}$ & EUR/pcs & 135 & 150 & 135 & 135 & 135 & 135 & 150 \\
\hline $\begin{array}{l}\text { 3. Exchange } \\
\text { rate }\end{array}$ & CZK/EUR & 22.8 & 24.0 & 24.0 & 24.0 & 25.4 & 24.0 & 25.4 \\
\hline $\begin{array}{l}\text { 4. Standard } \\
\text { of material } \\
\text { consumption }\end{array}$ & $\mathrm{Kg} / \mathrm{pcs}$ & 50 & 50 & 50 & 50 & 50 & 50 & 50 \\
\hline $\begin{array}{l}\text { 5. Purchase } \\
\text { price of } \\
\text { material }\end{array}$ & $\mathrm{CZK} / \mathrm{kg}$ & 44 & 44 & 40 & 44 & 44 & 36 & 40 \\
\hline $\begin{array}{l}\text { 6. Fixed } \\
\text { costs }\end{array}$ & Mil. CZK & 70 & 70 & 70 & 70 & 70 & 70 & 70 \\
\hline Profit & Mil. CZK & 9.02 & 84.0 & 66.4 & 44.4 & 65.19 & 88.4 & 129.1 \\
\hline
\end{tabular}

Source: Author's calculation

\section{Discussion}

As we showed in the previous parts, "what - if" analysis allows to obtain the certain idea of the project profit sensibility to simultaneous changes of two or more inputs and thus of the degree of forecasting risk. However, it is a useful, but not sufficient tool for the risk analysis. We have to think of its disadvantages, too. Some of them have already been outlined in the previous chapters. These include mainly the following ones:

- Concerning the fact that the choice of change in variables determining the financial criterion depends only the analyst's judgment, it is not obvious whether the set of changes characterizing the particular situation has a representative character. Concrete selection of changes and so the values of the input variables in the particular situations should respect their random nature.

- Getting good knowledge on variability of the financial criterion values - as well as on forecasting risk - it is necessary to make not tens, but hundreds or thousands 
of possible situations. Although we can do so by the use of computer, it is laborious.

- Information obtained by the use of "what - if" analysis do not provide the managers with the substantially evidentiary and quantified materials, on the basis of which it could be possible to decide on the realization of the project or activity, or recommend (or not recommend) their realization.

\section{Conclusion}

The most important thing to carry away from reading this paper is that estimated NPVs or returns should not be taken at face value. They depend critically on projected cash flows. If there is room for significant disagreement about those projected cash flows, the results from the analysis have to be taken with a grain of salt.

One possible way of defence against forecasting risk is simply to ask "what - if" questions, so the technique is also called a "what - if" analysis.

"What - if" analysis is a structured brainstorming method of determining what things can go wrong and judging the likelihood and consequences of those situations occurring. The answers to these questions form the basis for making judgments regarding the acceptability of those risks and determining a recommended course of action for those risks judged to be unacceptable.

The paper deals with three tools of "what - if" analysis: scenario, sensitivity and simulation analysis. Scenario and sensitivity analyses are useful tools for identifying which variables are critical to a project and where forecasting problems can do the most damage. If we combine the two approaches, all we get is a crude form of simulation analysis.

Despite the problems we have discussed, discounted cash flow is still the way of attacking problems, because it forces us to ask the right questions. But as the paper shows, knowing the questions to ask does not guarantee that we will get all the answers.

\section{References}

Belanová, K. (2009) Teória a politika podnikatel'ských financií (zbierka príkladov), Vydavatel'stvo EKONÓM, Bratislava, ISBN 978-80-225-2714-9.

Belanová, K. (2010) Teória a politika podnikatel'ských financií (praktikum), Vydavatel’stvo EKONÓM, Bratislava, ISBN 978-80-225-3109-2.

Campolongo, F. (2000) Sensitivity analysis as an ingredient of modeling, Statistical Science. Vol. 4, pp. 377-395.

Connor, G. (2010) Portfolio Risk Analysis. Princeton University Press, New Yersey. ISBN 978-08050-9134-2. 


\section{Financial Assets and Investing}

Chan, K. (2007) A quantitative, model independent method for global sensitivity analysis of model output. Technometrics. Vol. 1, pp. 39-56..

Chun, B. J. (1992) Scenario Analysis modeling and Decomposition methods for optimization under uncertainty. University of Wisconsin (dissertation), Madison.

Danielsson, J. (2011) Financial Risk Forecasting, Wiley, Chichester. ISBN 978-0-470-66943-3.

Hnilica, J, and Fotr, J. (2009) Aplikovaná analýza rizika ve finančním managementu a investičním rozhodování, Grada Publishing, Praha. ISBN 978-80-247-2560-4.

Law, A. (2006) Simulation Modeling and Analysis, McGraw Hill, N.Y. ISBN 978-0-072-98843- 7.

Saltelli, A. (1999) Sensitivity analysis. Could better methods be used? Journal of Geophysical Research. Vol. 3, pp. 3789-3793.

Saltelli, A. (2000) Handbook of Sensitivity Analysis. Wiley, Chichester. ISBN 978-0-471-99892-1.

Saltelli, A. (2004) Sensitivity Analysis in Practice: A guide to assessing scientific models. Wiley, Chichester. ISBN 0-470-87093-1.

Saltelli, A. (2007) Sensitivity Analysis. Wiley, Chichester. ISBN 978-0-470-74382-9.

Škrovánková, P. (2007) Spojité stochastické modely v zdravotnom a nemocenskom poistení.

Štatistické metódy v ekonómii (Conference proceedings), Bratislava ES EU, pp. 65-72.

DOI: 10.5817/FAI2012-3-1 